\title{
The Moderating Effect of Gender on the Relationship Between Intellectual Capital and Audit Quality
}

\author{
Williams Kwasi Peprah, Ph.D \\ School of Business, Valley View University. \\ Accra, Ghana
}

\begin{abstract}
In our globe today, the auditing profession is under scrutiny. This is because of how audit quality can be ensured, obtained, and maintained. The problem of audit quality is discussed from the viewpoint of intellectual capital and the interaction of the gender of the auditor. Audit quality consists of auditors' competence and independent, while intellectual capital is made up of human capital, rational capital, and structural capital. This research was a correlational design which applied self-constructed questionnaires with Cronbach alpha of 0.82 and 0.75 for intellectual capital and audit quality respectively. Using a convenience sampling technique, 354(8\%) out of 4,390 registered chartered accountants with Chartered Institute of Accountants, Ghana (ICA, GH) who were practicing auditors were used in this study. The study respondents were made up of $191(54 \%)$ males and 163 females, of which 210 (59.3\%) had attained degrees, and $144(40.7 \%)$ had an MBA. The study used PROCESS v3.2 and Andrew Haye model 1 to establish the regression and the moderating effect. The results of the study disclosed that there is a high positive significant relationship between intellectual capital and audit quality, and intellectual capital can predict audit quality by $53.68 \%$. Also, there is an enhancing moderating effect of gender on the relationship between intellectual capital and audit quality but not statistically significant. The study recommends that the role of the auditor on audit quality and their intellectual capital must not be differentiated. Therefore, attention must not be placed on the gender of the auditor to give a quality audit.
\end{abstract}

Keyword: Audit Quality, Intellectual Capital, Gender, Human Capital, Structural Capital, Rational Capital

\section{INTRODUCTION}

In our globe today, the auditing profession is under scrutiny. This is because of how audit quality can be ensured, obtained, and maintained. The auditor's function is essential for both inner and external economic data consumers. Auditors are relying on the financial statement to offer certainty and communicate an opinion. Financial data users believe that the auditor's information is free of bias and any material errors, hence their elevated audit performance expectations. Audit quality is derived from the competence and independence of auditors, according to Tepalagul and Lin (2015) and Persson (2011).

The world has experienced numerous problems related to auditing, but one that captured the attention of the globe is the Enron scandal. Because of their independence risk, their auditors Arthur Andersen were found for poor audit job (Yigit, 2013). Further research by Shahzad, Pouv, Rubbany, and El-Temtany (2018) also found that audit performance was a significant contributing factor to the global financial crisis. Audit failure as a vector of offering critical information for domestic and human development. The Bank of Ghana recently crashed seven banks in a rate of eight months from October 2017 to May 2018 in Ghana, and Peprah (2018) claimed that audit performance is attributable to the economic woes of the banking industry. 
The International Auditing and Assurance Standard Board (IAASB, 2014) has prepared a structure for audit quality due to the challenge of having a high standard audit quality. This standard is intended to ensure that auditing experts adhere to high-quality auditing, assurance, and norms. Also, to generate an audit public trust and its outcome. Again, the IAASB hopes to improve the consistency and quality of practice around the globe and to strengthen public trust in the worldwide assurance and auditing profession.

Intellectual capital is a critical factor to consider in terms of audit performance. Intellectual capital will determine the audit quality culture and will affect the efficiency of the structure and audit (Peprah \& Ganu, 2018). Intellectual capital is made up of rational capital, human capital, and structural capital (Abdelrhman \& Labib, 2014). Employing staff with the knowledge, abilities, and attitude for a quality audit is essential for an audit firm - Kang, Lee, Son, and Stain (2016) study note this suggestion. The intellectual capital used for this study will be human capital, rational capital, and structural capital.

According to Breesch and Branson, (2009), gender appears to have an important impact on the way information is gathered and processed from the current literature. Gender also tends to affect the risk profile significantly. Their research examined the impacts on the audit report and audit opinion of the auditor gender. In an audit context, only a restricted amount of research explored gender differences. It revealed that female auditor finds more prospective errors than male auditors, although less accurately analyzing the misstatement than male auditors. The results also show that female auditors are more risk-averse than masculine auditors.

In Taiwan, a study of gender on audit quality by Chin and Chi, (2008) when audit quality was represented by an evaluated by discretionary accruals and the probability that an opinion of going concern will be issued. The findings indicate that when audited by female signing auditors, customers have reduced discretionary accruals, irrespective of lead or concurrent auditors. Also, when both lead and competing auditors are female, customers have the least discretionary accruals. Finally, their research also demonstrated that with the number of male auditors, the variance in accruals improves monotonically. They also examine and discover that female auditors are much more likely to issue audit views than masculine auditors as an alternative measure of audit quality. They further discovered, however, that big four companies largely drive the greater tendency of female auditors to issue an ongoing concern view.

There is a scant report on audit quality, the impact of gender on audit quality as related to intellectual capitals when searching the literature in the context of Ghana. Given this, this research will attempt to fill the knowledge gap with the effect of intellectual capital on audit quality and the interaction effect based on the sex of the auditor. This study also purposes to figure out how to achieve high audit quality from the auditors ' view.

Peprah (2018) has reported that the auditor should be charged with the blame of the seven banks in Ghana recently. Therefore, the role of the auditor based on their gender as related to audit quality and intellectual capital is assessed with the following research questions: the study:

1. 1s there a significant relationship between intellectual capital and audit quality?

2. Is there a significant moderating effect of gender on the relationship between intellectual capital and audit quality? 


\section{Hypothesis}

The null hypothesis of this study will be:

1. There is no significant relationship between intellectual capital and audit quality.

2. There is no significant moderating effect of gender on the relationship between intellectual capital and audit quality.

There was no clear definition of the quality of the audit. The audit quality element focuses on professional standards, the process of operational auditing, and fraud detection. This helps decrease audit risk, enhance financial credibility, and attain the audit process objective. Auditors must create plans, budgets, and programs in the professional norms (Cameran, Prencipe, \& Trombetta, 2016). The financial resources used and the time invested in the audit are justified by these demands. They also highlight the prominence of oversight and audit performance. This is performed with due care of the professional. Professional due care enhances the auditor's capacity to detect and report mistakes and fraud that may occur in the accounts (Christensen, Glover, Omer, \& Shelley, 2016). The auditor's capacity to detect fraud reduces audit risk and increases the audited financial reports ' credibility. The goal is to fulfill the audit objective. Compliance with appropriate audit standards and processes is combined with audit quality (Krishnan, Krishnan \& Song, 2016). Audit quality is based on the connection between the client and the auditing firm (Goodwin \& Wu, 2016).

It is a necessity for an auditor to have the competence, and the auditor is obliged to keep ongoing professional understanding and abilities. This will help the auditor provide better service to the consumers of audited financial information and issue quality reports. Li, Lin, and Luo (2019) state that a well-educated, experienced, and competence in the accounting and auditing profession must perform the auditing inquiry well. Kertarajasa, Marwa, and Wahyudi (2019) argue that competence is the skill and capacity required to do a task or profession. Competent auditors are people who can perform their job with results of excellent quality. Competence comprises of understanding or mastery, abilities, and abilities that are insufficient and have attitudes that are suitable for doing a job or profession.

The audit committee enhances the independence of auditors by ensuring that the audit is free of influences from leadership (Endrawes, Feng, Lu, \& Shan, 2018). The auditors derive their authority from the audit committee to provide the management factors with a transparent and error-free audit report. According to Peprah (2018), independence of auditors is when auditors are free to objectively and truthfully evaluate, investigate, and provide certainty and conduct consulting services without any audit risk. Independence is the qualified likelihood of reporting a disclosed violation. Independence depends on the approach, honesty, and confidence of the auditors (Abbott, Daugherty, Parker, \& Peters, 2016).

The unique nature of the auditing job needs that each auditing firm's intellectual capital be large. Because of this, the audit company is aware of human capital, relational capital, and structural capital. This help improves the auditor's intellectual assets. With the auditors ' increasing criticism, there is an urgent need to bring the auditors ' performance-related problems to the attention (Attar, Kang \& Sohaib, 2019; Wang, Cai, Liang, Wang \& Xiang, 2018)). Because financial data consumers require a quality audit, intellectual capital has become the new strategic instrument to assist enhance the audit result.

Measurements and elements depend on the present the definitions of intellectual capital (Nikolovski, Zdravkoski, Menkinoski, \& Dicevska, 2016). Intellectual capital benefits auditing companies in the wealth creation of companies and competitive positioning (Hormiga, BatistaCanino, \& Sánchez-Medina, 2011; Chahal, \& Bakshi, 2015). This research goes hand in hand 
with the component concept that, given an audit performance result, intellectual capital is relational capital, human capital, and structural capital.

Human capital is the implicit or explicit understanding of the human mind (Guber, 2019). Auditors' ability to behave in ways to generate intangible and tangible assets is human capital (Demartini \& Trucco, 2016). Human capital is the inventory of the auditors ' abilities, knowledge, and abilities. Fitriyani and Mahmud (2017) have created that auditor's human capital consists of abilities, skills, and intellectual flexibility.

As far as relational capital is concerned, Dumay (2016) proposed it would include strategic partnerships, reputation, client relationships, and internal networks. It also involves customer satisfaction and customer loyalty, business authority, mental image, and environmental activity (Inkinen, (2015). Creating relational capital is not enough, but maintaining it and developing it.

When the auditors go back, structural capital is the leftovers in an audit firm's premises (Asiaei, Jusoh \& Bontis, 2018). The understanding of regulatory processes and intervention is linked to structural assets (Roos, \& Pike, 2018). It also reflected inside the audit company as the information organized and situated. Some take it that the information transformed to the property is structural capital (Hsu \& Wang, 2012). Lastly, the infrastructure is the structural capital of human capital.

Mitchell (2014) examined the connection that enhances audit performance between intellectual capital and disclosure. The research used was based on providing longitudinal scrutiny of intellectual capital disclosure procedures in the 1996-2000 period from the annual accounts of 31 FTSE 100 listed companies. The link between the performance of intellectual capital and the disclosure of intellectual capital was also explored. Between 1996 and 2000, the research verified an increase in intellectual capital disclosure. The findings did not identify a systematic connection between the performance of intellectual capital and the number of disclosures used during the study era. The result proposed that if the output of intellectual capital becomes too high, the quantity of disclosure will be lowered. The adverse connection endorsed the proposition that companies would lessen disclosures of intellectual capital when their output had reached a threshold level with fear of losing competitive advantage.

Gazor, Kohkan, Kiarazm, and Rastegari (2013) examined the achievement of the audit institution's association of intellectual capital. Intellectual capital is an asset used to generate competitive benefits by contemporary companies. They tried to investigate interactions in a conceptual model between variables of intellectual capital and performance of organizations in their research. In their studies, path analysis with Lisrel was used. The study's participants were both auditing and accounting firms accountants. Their findings showed that intellectual capital plays an important part in the success of the organization.

Karl Erik Sveiby (1997), Leif Edvinson (Edvinson and Malone, 1997) and RS Kaplan (Kaplan and Norton, 1992) popularized of intellectual capital theory. In intellectual capital, it has been noted that the human capital consists of knowledge, skills, and experience; the structural capital consists of the physical and non-physical facilities of the audit firm and relational capital comprising the connection with customers and the environmental elements.

The audit theory is used in this research to portray the quality of the audit. The theory of auditing considers accounting auditing. It needs an autonomous auditor to review the financial operations and statements of an organization. Its primary aim is to account for the economic 
transaction of the company correctly and fairly without any impact or misrepresentation of content.

\section{METHODOLOGY}

This research is correlational design. It is a quantitative study which used parametric inferential statistics to analyze the data. The respondents of this study were the Institute of Chartered Accountants, Ghana (ICA) members. The data from ICA, Ghana stated that there were 4,390 chartered members in good standing as at May 2019 and based on Raosoft sample size calculator 354 members were conveniently sampled for the study at a $95 \%$ confidence interval. Only practicing chartered accountants or chartered members working in an audit firm were sampled to answer the self-constructed questionnaires. The respondents answered selfconstructed questionnaires, which had an internal consistency of 0.82 and 0.75 based on the Cronbach Alpha for intellectual capital and audit quality, respectively. Question one and two were analyzed by using the regression Process v3.2 by Andrew F. Hayes model 1, as shown in figure 1 to find both the relationship and conditional effect of gender. The magnitude of the strength of the relationship is determined and interpreted on the absolute values of Cohen (1988) where $r=.10$ to.29 is small/low, $r=.30$ to.49 is medium/ moderate, and $r=.50$ to 1.0 is large/high.

By following the format of Jose (2013), Haye (2009) and Hayes and Matthes (2009), the assessment of the moderation effect is described and submitted. An impact of moderation that is an impact of interaction is viewed either as enhancing or as antagonistic (Hayes \& Matthes, 2009). An enhancing moderation effect is when an increase in the moderator quantity (gender) causes an increase in the independent variable's (intellectual capital) influence on the dependent variable (audit quality). This implies that a predictor shift owing to the implementation of a moderator will have a positive effect on the criterion in the connection between the predictor. All of them lead to a beneficial enhancement. An antagonistic effect is when a moderator (gender) rise produces a reverse impact on the dependent (audit quality) of the independent variable (intellectual capital). This means that a predictor shift owing to the implementation of a moderator creates a negative effect on the criterion of the connection between the predictor. It will cause the issue to deteriorate. 
Independent Variable

Dependent Variable

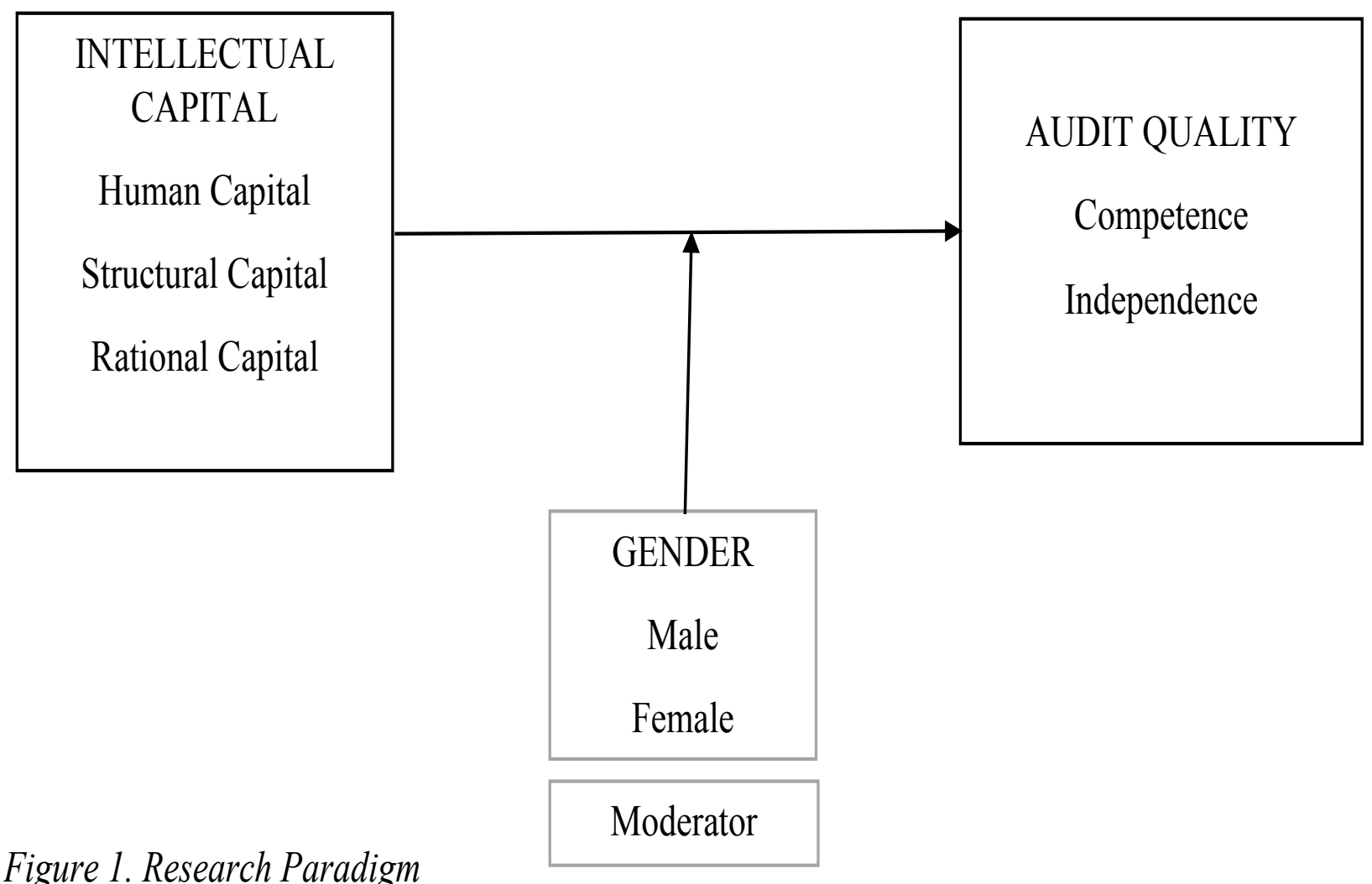

RESULTS AND DISCUSSION

The engaged practicing auditors used in this study were made up of 191 (54\%) males and 163 females of which $210(59.3 \%)$ had attained degrees, and 144 (40.7\%) had MBA. In the study, males are represented by 1 and female by 2 for statistical encoding for gender interpretations.

In examining the relationship between intellectual capital and audit quality, the study revealed that there is a high positive significant relationship between intellectual capital and audit quality $(\mathrm{r}=.7327, \mathrm{p}=.000)$ as showed in Table 1 . Also, it indicated that intellectual capital could account of audit quality by $53.68 \%\left(\mathrm{r}^{2}=0.5368\right)$. These results are presenting that in order to attain audit quality, attention must be placed on intellectual capital. Table 1

Moderating Effects of Gender on the Relationship Between Intellectual Capital and Audit Quality

\begin{tabular}{|c|c|c|c|c|c|c|c|c|c|c|}
\hline & $\mathrm{R}$ & $\mathrm{R}^{2}$ & $\mathrm{~F}$ & df1 & $\mathrm{df} 2$ & $\mathrm{~T}$ & $B($ Coeff $)$ & $\mathrm{P}$ & IV & $\begin{array}{c}\text { Moderation } \\
\text { Effect } \\
\text { Low Medium } \\
\text { High } \\
\end{array}$ \\
\hline Summary Model & 0.7327 & 0.5368 & 135.2133 & 3 & 350 & & & .000 & S & \\
\hline & & & & & & & & & & $\begin{array}{c}\text { Enhancing } \\
\text { Effect }\end{array}$ \\
\hline Interaction Model & & 0.002 & 1.5256 & 3 & 350 & -1.2352 & -0.089 & 0.2176 & NS & \\
\hline
\end{tabular}


By this result, the study rejects the null hypothesis that there is no significant relationship between intellectual capital and audit quality. The outcome of this investigation is contrary to Mitchell (2014), which recorded that intellectual capital had no significance on audit quality element of disclosures. However, this results is a confirmation of similar results by Gazor, Kohkan, Kiarazm, and Rastegari (2013) which stated that there is a significant relationship between intellectual capital and audit quality for organizational success.

In analyzing for the moderating effect of gender on the relationship of intellectual capital and audit quality, the initial investigation was the two predictors of intellectual capital and gender were regressed on the criterion audit quality. The summary model resulted in a significant value of variance on political intensity $R^{2}=.05368, F(3,350)=135.2133, p=.000$. Then the interaction of intellectual capital and gender was introduced. This moderating variable generated a non-significant change in the process called the interaction model $\Delta \mathrm{R}^{2}=.0 .002$, $\Delta \mathrm{F}(3,350)=1.5256, \mathrm{p}=.0 .2176, \mathrm{~b}=.-0.089, \mathrm{t}(350)=1.2352$. In scrutinizing the interaction plot as noted in Table 1 and figure 2, it showed an enhancing effect that as intellectual capital and gender increased, audit quality increased but it is not statistically significant.

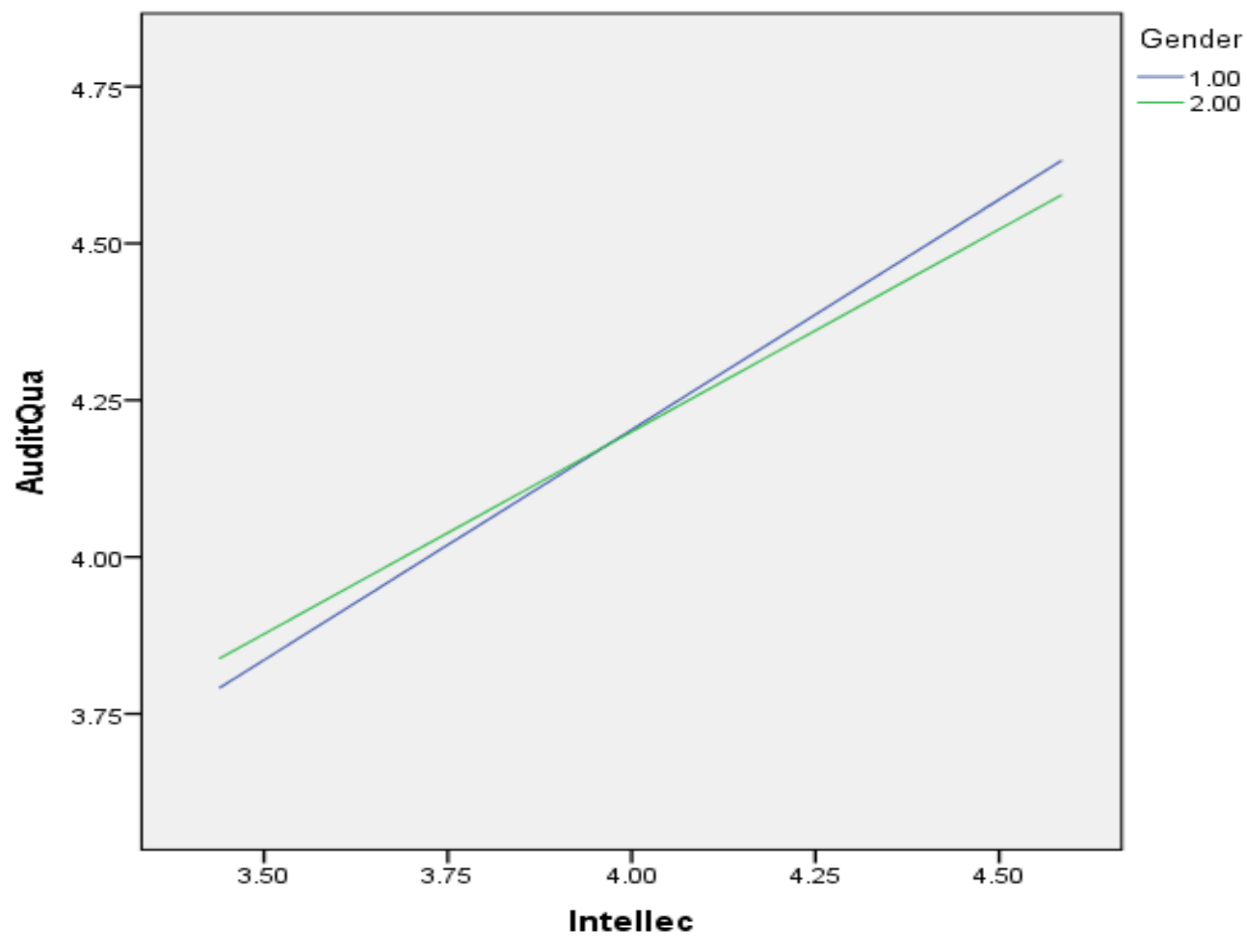

\section{Figure 2. Enhancing Effect of Gender on the Relationship Between Intellectual Capital and Audit Quality.}

Therefore, the study fail to reject the null hypothesis that there is no moderating effect of gender on the relationship between intellectual capital and audit quality. This result is contrary to Breesch, and Branson (2009) and Chin and Chi (2008) who placed more significance of females for audit quality than males. They noted that females could detect error and prevent material omission than males. However, the outcome of this study in Ghana has revealed that as far as intellectual capital is a concern, gender do not differ on the audit quality. This implies that males and female practicing auditor view on audit quality amidst intellectual capital is not different, and they see both as essential elements with a positive correlate. 


\section{RECOMMENDATION}

The study has exposed that intellectual capital has a significant positive relationship with audit quality. In that, it can predict audit quality positively. However, the gender impact of the practicing auditors on the thought of audit quality does not differ because the interaction is not statistically significant. This study recommends that the role of the auditor on audit quality and their intellectual capital must not be differentiated. Therefore, attention must not be placed on the gender of the auditor to give a quality audit.

\section{Reference}

Abbott, L. J., Daugherty, B., Parker, S., \& Peters, G. F. (2016). Internal audit quality and financial reporting quality: The joint importance of independence and competence. Journal of Accounting Research, 54(1), 3-40.

Abdelrhman, A.N. \& Labib, K.Z. (2014). Measuring audit firms' intellectual capital as a determinant of audit quality: A suggested model. Journal of Modern Accounting and Auditing, 10(1), 59-79.

Asiaei, K., Jusoh, R., \& Bontis, N. (2018). Intellectual capital and performance measurement systems in Iran. Journal of Intellectual Capital, 19(2), 294-320.

Attar, M., Kang, K., \& Sohaib, O. (2019). Knowledge Sharing Practices, Intellectual Capital and Organizational Performance. In Proceedings of the 52nd Hawaii International Conference on System Sciences.

Breesch, D., \& Branson, J. (2009). The effects of auditor gender on audit quality. IUP Journal of Accounting Research \& Audit Practices, 8 .

Cameran, M., Prencipe, A., \& Trombetta, M. (2016). Mandatory audit firm rotation and audit quality. European accounting review, 25(1), 35-58.

Chin, C. L., \& Chi, H. Y. (2008). Gender differences in audit quality. In 2008 American Accounting Association annual meeting.

Christensen, B. E., Glover, S. M., Omer, T. C., \& Shelley, M. K. (2016). Understanding audit quality: Insights from audit professionals and investors. Contemporary Accounting Research, 33(4), 1648-1684.

Cohen, J. W. (1988). Statistical power analysis for the behavioral sciences (2nd ed.). Hillsdale, NJ: Lawrence Erlbaum Associates.

Demartini, C. \& Trucco, S. (2016). Does intellectual capital disclosure matter for audit risk? Evidence from the UK and Italy. Sustainability 2016, 8, 867; doi:10.3390/su8090867.

Dumay, J. (2016). A critical reflection on the future of intellectual capital: from reporting to disclosure. Journal of Intellectual capital, 17(1), 168-184.

Endrawes, M., Feng, Z., Lu, M., \& Shan, Y. (2018). Audit committee characteristics and financial statement comparability. Accounting \& Finance.

Gazor, H., Kohkan, F., Kiarazm, A., \& Rastegari, H. (2013). Impact of Intellectual Capital on Performance in Audit Institutes. Asian Journal of Finance \& Accounting, 5(1). doi:10.5296/ajfa.v5i1.2682.

Goodwin, J., \& Wu, D. (2016). What is the relationship between audit partner busyness and audit quality?. Contemporary Accounting Research, 33(1), 341-377.

Guber, R. (2019). Making it right? Social norms, handwriting and human capital. Labour Economics, 56, 44-57.

Hayes, A.F. (2009). Beyond Baron and Kelly: Statistical mediation analysis in the new millennium. Communication Monograph, 76, 408-420. Doi: 10.1080/03637750903310361.

Hayes, A.F., \& Matthes, J. (2009). Computational procedures for probing interactions in OLS and logistic regression: SPSS and SAS implementations. Behavior Research Methods, 41, 924-936.

Hormiga, E., Batista-Canino, R. M., \& Sánchez-Medina, A. (2011). The role of intellectual capital in the success of new ventures. International Entrepreneurship and Management Journal, 7(1), 71-92.

Hsu, L., \& Wang, C. (2012). Clarifying the effect of intellectual capital on performance: The mediating role of dynamic capability. British Journal of Management, 23(2), 179-205.

IAASB (2014). A Framework for Audit Quality Key Elements That Create an Environment for Audit Quality. Retrieved from: https://www.ifac.org/publications-resources/framework-audit-quality-key-elements-createenvironment-audit-quality. 
Inkinen, H. (2015). Review of empirical research on intellectual capital and firm performance. Journal of Intellectual capital, 16(3), 518-565.

Jose, P.E. (2013). Doing statistical mediation and moderation. New York: Guilford Press.

Kang, M., Lee, H., Son, M., \& Stein, M. (2016). The association between human resource investment by audit firms and their audit quality. Asia-Pacific Journal of Accounting \& Economics, 24(3-4), 249-271. doi:10.1080/16081625.2016.1214605.

Kertarajasa, A. Y., Marwa, T., \& Wahyudi, T. (2019). The effect of competence, experience, independence, due professional care, and auditor integrity on audit quality with auditor ethics as moderating variable.

Krishnan, J., Krishnan, J., \& Song, H. (2016). PCAOB international inspections and audit quality. The Accounting Review, 92(5), 143-166.

Li, X., Lin, Z., \& Luo, J. H. (2019). Does auditor-client distance matter to real earnings management? Evidence from China. Asia-Pacific Journal of Accounting \& Economics, 1-

Mitchell W. S. (2014). Is intellectual capital performance and disclosure practices related?. Journal of Intellectual capital, 2(3), 192-203.

Nikolovski, P. Zdravkoski, I., Menkinoski, G. \& Dicevska, S. (2016). The concept of audit risk. International Journal of Science Basic and Applied Research, 27(1)24-31.

Peprah, W. K., \& Ganu, J. (2018).The convergence of organizational culture, structure and human capital performance: A conceptual analysis. Archives of Business Research, 6(5), 212-221. DOI:10.14738/abr.65.4626.

Peprah, W.K. (2018, August 6). Auditors' independence risk: The primary contributing factor in the financial sector's woes. Business \& Financial Times, p. $9 \& 17$.

Persson, U. (2011). Factors affecting audit quality: Number of assignments and age of auditors. Master's Thesis: Umea School of Business. Norway.

Roos, G., \& Pike, S. (2018). Intellectual Capital as a Management Tool: Essentials for Leaders and Managers. Routledge.

Shahzad, K., Pouv, T., Rubbany, G. \& El-Temtamy, O. (2018). Audit quality during the global financial crisis: The investors' perspective. Research in International Business Finance, 45, 94-105, https://doi.org/10.1016/j.ribaf.2017.07.137.

Tepalagul, N., \& Lin, L. (2015). Auditor independence and audit quality: A literature review. Journal of Accounting, Auditing \& Finance, 30(1), 101-121.

Wang, Z., Cai, S., Liang, H., Wang, N., \& Xiang, E. (2018). Intellectual capital and firm performance: the mediating role of innovation speed and quality. The International Journal of Human Resource Management, 1-29.

Yigit, B. S. (2013). Auditor Independence: The Case of Arthur Andersen and Enron. International Conference on Economic and Social Studies, 10-11 May, 2013, Sarajevo, 1 (1). 


\section{Run MATRIX procedure:}
************** PROCESS Procedure for SPSS Version 3.2.01
Written by Andrew F. Hayes, Ph.D. www.afhayes.com
Documentation available in Hayes (2018). www.guilford.com/p/hayes3 $* * * * * * * * * * * * * * * * * * * * * * * * * * * * * * * * * * * * * * * * * * * * * * * * * * * * * * * * * * * * * * * * * * * * * * * * * * * *$
Model : 1
Y : AuditQua
$\mathrm{X}:$ Intellec
W : Gender
Sample
Size: 354

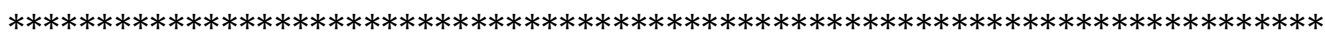

OUTCOME VARIABLE:

AuditQua

Model Summary

$\begin{array}{ccccccc}\mathrm{R} & \mathrm{R}-\mathrm{sq} & \mathrm{MSE} & \mathrm{F} & \mathrm{df1} & \mathrm{df} 2 & \mathrm{p} \\ .7327 & .5368 & .1252 & 135.2133 & 3.0000 & 350.0000 & .0000\end{array}$

Model

$\begin{array}{lcccccc} & \text { coeff } & \mathrm{se} & \mathrm{t} & \mathrm{p} & \mathrm{LLCI} & \mathrm{ULCI} \\ \text { constant } & .9131 & .4290 & 2.1285 & .0340 & .0694 & 1.7568 \\ \text { Intellec } & .8232 & .1057 & 7.7888 & .0000 & .6154 & 1.0311 \\ \text { Gender } & .3528 & .2893 & 1.2194 & .2235 & -.2163 & .9219 \\ \text { Int_1 } & -.0890 & .0720 & -1.2352 & .2176 & -.2307 & .0527\end{array}$

Product terms key:

Int_1 : Intellec x Gender

Covariance matrix of regression parameter estimates: constant Intellec Gender Int_1

$\begin{array}{lcccc}\text { constant } & .1840 & -.0449 & -.1172 & .0287 \\ \text { Intellec } & -.0449 & .0112 & .0287 & -.0072 \\ \text { Gender } & -.1172 & .0287 & .0837 & -.0207 \\ \text { Int_1 } & .0287 & -.0072 & -.0207 & .0052\end{array}$

Test(s) of highest order unconditional interaction(s):

$\begin{array}{cccccc} & \text { R2-chng } & \mathrm{F} & \mathrm{df1} & \mathrm{df2} & \mathrm{p} \\ \mathrm{X}^{*} \mathrm{~W} & .0020 & 1.5256 & 1.0000 & 350.0000 & .2176\end{array}$

Focal predict: Intellec $(\mathrm{X})$

Mod var: Gender (W)

Data for visualizing the conditional effect of the focal predictor:

Paste text below into a SPSS syntax window and execute to produce plot. 
DATA LIST FREE/

Intellec Gender AuditQua . BEGIN DATA.
$3.4390 \quad 1.0000$
3.7910
$\begin{array}{lll}4.0000 & 1.0000 & 4.2029\end{array}$
$\begin{array}{lll}4.5854 & 1.0000 & 4.6327\end{array}$
$\begin{array}{lll}3.4390 & 2.0000 & 3.8379\end{array}$
$\begin{array}{lll}4.0000 & 2.0000 & 4.1998\end{array}$
$4.5854 \quad 2.0000 \quad 4.5776$

END DATA.

GRAPH/SCATTERPLOT= Intellec WITH AuditQua BY Gender .

\section{ANALYSIS NOTES AND ERRORS}

Level of confidence for all confidence intervals in output:

95.0000

NOTE: Standardized coefficients not available for models with moderators.

NOTE: Variables names longer than eight characters can produce incorrect output. Shorter variable names are recommended.

END MATRIX ----- 